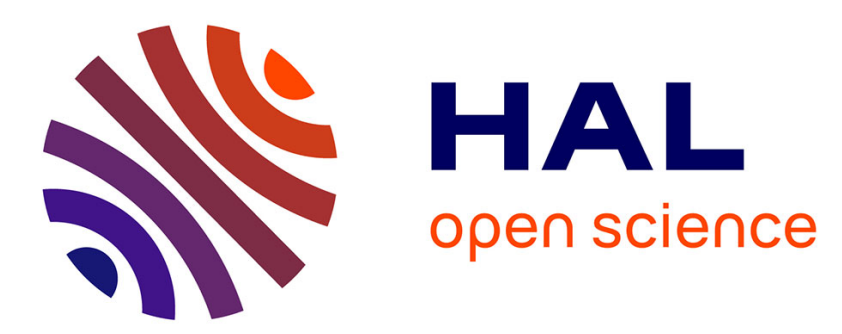

\title{
Emergence of Economic Institutions: Analysing the Third Role of universities in Turku, Finland
}

\author{
Smita Srinivas, Kimmo Viljamaa
}

\section{To cite this version:}

Smita Srinivas, Kimmo Viljamaa. Emergence of Economic Institutions: Analysing the Third Role of universities in Turku, Finland. Regional Studies, 2008, 42 (03), pp.323-341. 10.1080/00343400701291534 . hal-00514668

\section{HAL Id: hal-00514668 \\ https://hal.science/hal-00514668}

Submitted on 3 Sep 2010

HAL is a multi-disciplinary open access archive for the deposit and dissemination of scientific research documents, whether they are published or not. The documents may come from teaching and research institutions in France or abroad, or from public or private research centers.
L'archive ouverte pluridisciplinaire $\mathbf{H A L}$, est destinée au dépôt et à la diffusion de documents scientifiques de niveau recherche, publiés ou non, émanant des établissements d'enseignement et de recherche français ou étrangers, des laboratoires publics ou privés. 


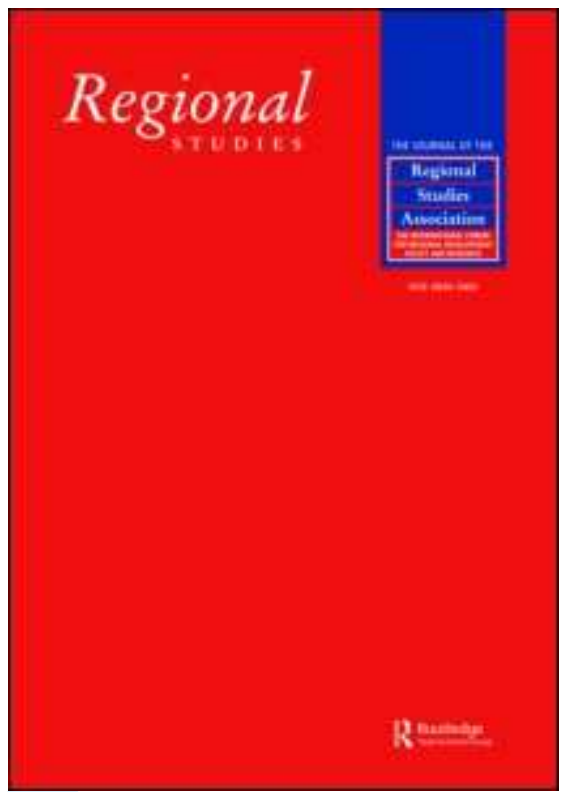

\section{Emergence of Economic Institutions: Analysing the Third Role of universities in Turku, Finland}

\begin{tabular}{|c|l|}
\hline Journal: & Regional Studies \\
\hline Manuscript ID: & CRES-2005-0213.R2 \\
\hline Manuscript Type: & Main Section \\
\hline JEL codes: & $\begin{array}{l}\text { D00 - General < D0 - General < D - Microeconomics, O21 - } \\
\text { Planning Models } / \text { Planning Policy < O2 - Development Planning and } \\
\text { Policy < O - Economic Development, Technological Change, and } \\
\text { Welfare, R11 - Regional Economic Activity: Growth, Development, } \\
\text { and Changes < R1 - General Regional Economics < R - Urban, } \\
\text { Rural, and Regional Economics }\end{array}$ \\
\hline Keywords: & $\begin{array}{l}\text { Economic development , Institutions, Planning models, Urban and } \\
\text { regional development, Science and Technology policy, Finland }\end{array}$ \\
\hline \hline
\end{tabular}

\section{SCHOLARONE \\ Manuscripts}


Emergence of Economic Institutions:

\author{
Analysing the Third Role of universities in Turku, Finland \\ SMITA SRINIVAS* and KIMMO VILJAMAA** \\ *Urban Planning Program, Columbia University, Graduate School of Architecture, Planning and \\ Preservation, 1172 Amsterdam Avenue, New York, NY 10027, USA. Email: ss3079@ columbia.edu \\ **Research Unit for Urban and Regional Development Studies, University of Tampere, 33014 \\ University of Tampere, Finland. Email: kimmo.viljamaa@uta.fi
}

\begin{abstract}
How do universities become economic development institutions? The normative "Third Role" in Europe refers to universities taking on explicit economic development mandates such as greater technology transfer, and commercial outputs, without providing much of a compass for institutional change. We argue that universities transform themselves into economic institutions against a changing canvas of national welfare by a process of "task-oriented institutionalisation" which involves both individual action and university strategy. We investigate two universities' interactions with firms in Turku, Finland's biotechnology concentration. Using universities as a lens, we find notable gaps in frameworks on how economic institutions emerge, and conclude with five hypotheses for future studies on universities, institutions and economic development.
\end{abstract}

Keywords: Economic development, institutions, planning models, universities, urban and regional development, science and technology policy, Finland

JEL: D02, O21, I23, R11

\title{
INTRODUCTION
}

There has been new form and impetus in recent years to the idea that economic development and the welfare of regions can emerge through universities' engagement with the local economy and 
particularly via technological innovations. In this paper, we take as a starting point that the engagement of universities in the economy is the archetype of a process of emergent institutional change. We show that these emergent processes are specific to location, and represent the meshing of the idea of national welfare with (as is the case here) local incorporation of technological advances in pharmaceuticals and the life-sciences. Importantly, they pull away significantly from rational planning paradigms that technology policies have traditionally represented.

History shows that the role of the university has been contested. It faces numerous tensions education, research, training, technology transfer or assisting in broader economic development. More generally, university-industry interactions seem to have been subsumed into broader analytical as well as normative policy debates for both technological innovation and local and regional development (for example, GIBBONS et al., 1994; ETZKOWITZ and LEYDESDORFF, 2000; HARLOE and PERRY, 2004; CHATTERTON and GODDARD, 2000). This is especially visible in Finland, but reflects a worldwide trend, where the economic development "Third Role" of universities has been given increasing attention in at least three spheres: urban and regional economic development, higher education and science and technology policies. From a regional perspective, universities appear to be increasingly viewed as an economic asset especially because unlike firms, they are relatively permanent institutions and therefore "safer" for development policy measures.

\section{“TASK-ORIENTED” INSTITUTIONALISATION}

As we will discuss in the paper, universities like firms, are organisations and institutions (on this topic, see HODGSON 2006). As such, they not only have internal functions and characteristics as all organisations do, but they are also 'systems of established and prevalent social rules that structure social interactions' (ibid., p. 2). We will discuss this at much greater length in our framework before we begin the case study of Turku. Thus, economic policies are as much about economic impact as they are about assumptions regarding institutional formation and change. 
Our question is: how do institutions become institutions for economic development? What are the origins of action and change? To do this, we focus on one aspect of the Third Role approach-the calls for increased interaction between universities and firms in the region. We argue here that the Third Role calls for universities to transform themselves into economic institutions (among other roles) by taking on specific tasks such as greater technology transfer, more patenting, visible employment and commercial outputs. The list is much longer. We thus break our question into processes and ask (a) what persuades universities and industry to work together? (b) what persuades universities to become involved with a regional development mandate to flesh out the idea of 'taskoriented' institutionalisation such as the "Third Role" calls for? So we ask that while normatively, universities perhaps 'should' interact with firms, how, when and why do they? Who begins the interaction or is this the proverbial chicken-and-egg problem in institutionally 'underdeveloped' regions, with reluctance on both sides? These questions are important for many reasons. Even if relatively successful interactions take place between university and industry, it is often unclear whether the university might have strategic intent in shaping the interaction, whether universities could do more to fulfil a 'third role' of regional development and whether and how public policy has influenced it. It also allows an investigation of the normative elements of institutional development contrasted with real-world processes of economic change.

As discussed, there has been an immense push worldwide to use technological innovations in various sectors as an economic and regional development base. The city-region of Turku is one such landscape and today is of the main centres of biotechnology research in the Nordic countries and the second biggest concentration of biotechnology activities in Finland after Helsinki. Turku was the capital until the $18^{\text {th }}$ century and the site of Finland's first university. Its economic development fortunes for centuries have been closely interwoven with those of the pharmacies, pharmaceuticals, food and biomedical specializations. As this paper discusses, there exist a complex mix of relations between academia and industry and a specific regional development history. Turku 
is thus an excellent site for the study of the "Third Role" and its universities' actual engagement with economic development. It also provides a very suitable lens from which to study a move from practice to theory regarding institutions and economic development.

We will thus proceed in two parts. The first part reviews conceptualizations of universities as institutions within economy and society and the changed environment regarding public welfare in which this relationship is being assessed. The first part ends by introducing our preliminary approach (individual vs. institutional action) of "task-orientation", to better understand the processes of the Third Role. The second part looks at the specific case of the biotechnology concentration in Turku and is divided into institutional threads that show the complexity of circumstances under which the two universities engaged with broader regional development. The paper argues that while some elements of environmental change were common to all of Finland, (indeed some such as cuts in public spending are common to other parts of Europe), some specific circumstances uniquely shaped the institutional development of Turku and its two universities. The paper concludes with further discussion of theorising regarding "task-oriented" institutionalisation and challenges for economic development policies embedded in the Third Role.

\section{CONCEPTUALISING THE THIRD ROLE}

The University and its Environment: technological knowledge as public welfare

In the contemporary literature, three primary conceptualisations on the role of academic research within the economy can be distinguished (MOWERY and SAMPAT, 2004; ETZKOWITZ and LEYDESDORFF, 2000): the extensive literature on innovations systems with national (e.g. LUNDVALL, 1992; NELSON, 1993), regional (e.g. COOKE et al., 2004) and sectoral (e.g. MALERBA, 2002) focus; the "dynamic mode of interaction" approach (GIBBONS et al., 1994) and the Triple Helix framework (ETZKOWITZ and LEYDESDORFF, 2000). From a specific focus on knowledge institutions there is also an emerging literature on the engaged university (OECD 
1999; CHATTERTON and GODDARD, 2000; HOLLAND 2001). This approach concentrates especially on how universities adapt by creating a stronger regional focus in their teaching and research. Despite differences in their focus, these approaches share the idea that knowledge and innovation have become increasingly important sources of national economic differentiation and that innovation processes as interactive, require collaboration between actors in different spheres. Overall, there is growing consensus that universities can play a significant role in regional economic development in a variety of ways.

However, there has also been a lot of critique and doubts about the feasibility of the new third role of universities. Some have raised the spectre of 'academic capitalism' (SLAUGHTER and LESLIE 1997). There are, for example, worries that might move the university research away from basic to more applied research or that the formal university-industry technology transfer mechanisms create unnecessary costs (e.g. patents and licensing) to knowledge that could advance the economy better when flowing freely (ROSENBERG and NELSON, 1994) or in the way that it weakens the commitments to open science, causing increasing secrecy (EISENBERG and NELSON, 2002; DASGUPTA and DAVID, 1994). This reflects the debate on more traditional 'Mode 1' of knowledge generation, anchored in disciplines, and which is homogenous and hierarchical, versus 'Mode 2', where knowledge is increasingly generated in the context of application (ZIMAN, 1996; CHATTERTON and GODDARD, 2001). This debate is perhaps more critical of the outcomes of university engagement than the 'entrepreneurial university' perspective (ETZKOWITZ and LEYDESDORFF, 2000; MARTIN and ETZOWITZ, 2000). We will argue that these reflect broader national shifts in models of welfare, employment and economic governance and may not require separation of two institutional spheres of activity puling in opposite directions, where welfare states are seen as inimical to economic well-being.

There have also been several institutional and technological changes in the universities' external environment that have put increased pressures on universities. These are, amongst others, the 
changing of higher education from education of the elite to that of the masses, the emphasis on lifelong learning, striving for effectiveness of public funding, the new alternative methods for knowledge production and dissemination and the new educational methods provided by the information and communication technologies (VIRTANEN, 2002; see also GODDARD, 1999; CHATTERTON and GODDARD, 2000). As we will see, these newer concepts of welfare and pressures on universities arising from various technological and economic changes, have affected Turku's economic trajectory as well.

The National Welfare Context-the origins of the Finnish “Third Mission” policies

As earlier scholars have pointed out (e.g. HARLOE and PERRY, 2004; AROCENA and SUTZ, 2000), local context continues to matter in analysing universities. The extent to which, and the rules by which, they can be 'territorialized' deserves some study (LAWTON SMITH, 2003). While some recent studies on Turku have mentioned the role of the universities to varying degrees (HÖYSS $\ddot{A}$ et al., 2003; BRUUN, 2002; ORAVA et al., 2001; SCHIENSTOCK and TULKKI, 2001) we bring it to the forefront and hope to provide a theoretical framework to Turku's development (and dilemmas) by explaining the precise circumstances of economic institutionalisation of the Third Role.

Yet, it is worth reflecting on the fact that these debates are not new; they reflect ever-changing societal contexts within which to view knowledge production and social use. They also reflect debates of market and non-market-oriented activity and the place of the university as a broader welfare-embodying institution. Each has varied emphasis on a privileged state (SÁBATO and MACKENZI, 1982), privileged firm (LUNDVALL, 1988, 1992, NELSON, 1993), or other privileged institution (ETZKOWITZ and LEYDESDORFF, 2000) and has distinct national variants. Both production and distribution of the types of technological knowledge that many universities embody are social processes that were re-fashioned from a social contract nationally 
devised after World War II in many countries, but have seen considerable wear and debate since then (JASANOFF, 2003; STOKES, 1997).

Moreover, the innovation policy approach has emphasized networking and cooperation between universities and other societal actors, various centres of expertise and commercialisation of university research (SCHIENSTOCK and HÄMÄLÄINEN, 2001). In practice, especially important in Finland has been the tighter constraints on public funding and the change in the state funding structure from budget funding to more competitive funding mechanisms (FELLER, 2004; NIEMINEN and KAUKONEN, 2001). The economic constraints have driven universities to increase business funding and competitive public funding that often requires public-private partnerships. Universities have also become more active in other commercialisation activities, such as technology licensing, patenting, support for start-up companies and entrepreneurial training (MIETTINEN et al., 2006). The Science and Technology Council of Finland (2000; 2003) as well as Ministry of Education (2001) have highlighted the question of social, economic and regional impact of the universities and even university legislation has been pushed in this direction. Starting from 2002, universities have been obliged to prepare a regional strategy and in the new Universities Act (715/2004) a new "third mission" was formally introduced to universities in 2004. There has also been an increased interest from local and regional governments towards the universities. With their strategies in almost every region relying on knowledge and learning the pressure towards universities to act as economic engines has increased (VIRTANEN, 2002; NIEMINEN and KAUKONEN, 2004). All in all, during the past few decades the Finnish universities have been given various new tasks. This has placed considerable strains to the university system, as the old and the new tasks have not always been easy to combine (MIETTINEN et al., 2006).

Our analysis shows that while today, the third role of Universities has recently been given a great deal of attention in Finland in both Higher Education and Science \& Technology policies as well as in the academic debate (VIRTANEN, 2002; KANKAALA et al., 2004), it arose from gradual shifts 
in Nordic welfare regimes. In Finland, this has become visible in changing governance and internal management of Finnish universities resulting from broader moves to reduced public spending and changed perceptions of the Welfare state. Public universities and free education were earlier considered an important component of social infrastructure in the shift from agrarian to industrial and then a post-industrial economy (ANTIKAINEN 1980; 1981). The regional impacts of the decentralised higher education system and regional development policies (and the roles of universities) grew out of rapid industrial changes in Finland that shaped the flow of immense migration into industrial centres in Southern Finland. JOLKKONEN (1984) reveals how industrialisation was the mother of the university system in Finland, and national conflicts were midwives in helping give birth to them (ANTIKAINEN and JOLKKONEN, 1994). These emerged in different forms-from research-intensive universities to others, those catering primarily to local regions, those with wider student recruitment, and those with greater or less engagement in studies of local welfare and 'regional culture'.

The university system in Finland evolved with the Finnish welfare state, and nationalisation of private universities occurred. Development laws assured the growth trajectories of university resources and were ratified in the 1960s such that higher education was treated as one of many public services provided by the welfare state (ANTIKAINEN and JOLKKONEN, 1994). Combining medium labour market regulation with a universalist but non-familialist welfare state, the Finnish strategy focused on generous benefits and was egalitarian in spirit. Public education was free and the university considered an integral component of public welfare. Furthermore, the emphasis on direct public-service provision in the Nordic countries ensured that almost a third of total employment could be explained by public employment, yet long-run productivity lags in the public sector and a compressed wage structure created upward pressures on taxation (ESPINGANDERSEN, 1999). The resultant weakening of political consensus on appropriate future strategies for sustaining high employment had repercussions in public employment. Across the Nordic 
countries, public employment as a strategy to higher employment had been growing since the 1960s but now witnessed cuts (ibid.). Public universities and their associated services were no exception. The failures of traditional regional policy were also evident in the 1980s: industry expansion was slowing, there was agricultural overproduction and a call to halt state subsidies and infrastructure was substantial. Thus, there was a pause and reconsideration of Finland's direction for development into a 'post-industrial' society (ibid.) alongside an increasing view of public services from an efficiency standpoint, and a more demanding focus on productivity and competitiveness (KOSONEN, 1987). The early 1990s witnessed the enormous Finnish economic crisis, thus exacerbating the push to an "information-society" and pressures for a new vision for universities. The identification of universities as an integral part of public and social policy came at a price; during the recession 'welfare services' were cut and the university budget along with it (ibid.). Thus, while overall there was been a retrenchment in many Nordic countries on the side of public funding for social service, insurance and wage bargaining, the idea of welfare has not disappeared. We concur that it has changed form into a gradual bolstering for public policies for research and innovation (BENNER, 2003). These reflect a change in linkages between technological advances in certain industries, political alliances, the functions of a welfare state and the form that welfare takes via economic development.

These social contracts however, may increasingly be locally questioned in terms of the specificities of the Third Role and local (national and regional) differences. In Finland, for example, the universities are distinct from universities in the U.S. because all Finnish universities are state-run institutions and primarily financed from the state budget. Even though the universities have extensive autonomy, they are in many ways affected by the educational legislation and the overall lines of education and research policy. Furthermore, they differ from most of their counterparts elsewhere in Europe because of significantly above average rate of both formal and informal collaboration with industry in recent years (POLT et al., 2001). From a regional perspective, 
universities have begun to be viewed as an economic asset especially because unlike firms, they are relatively permanent institutions and therefore "safer" targets for development policy measures. While, until the 1950s universities were concentrated in Helsinki and Turku, Finland developed a decentralised system of higher education rapidly between 1960 and 1980, a very short period of time. Antikainen (1981) paints a picture of relative reticence by universities, but active involvement by individuals and departments in their surrounding region. Today, universities are facing tighter constraints on public funding and seek new sources of funding, which has lead at least some of the universities to become "entrepreneurial" in their practices (MOWERY and SAMPAT, 2004). These same pressures are visible in Finland. Although in the Finnish case, there may have been less erosion of traditional academic practices, values and ideals despite increasing market-orientation and decreased budget funding, a balance between such 'traditional' practices and more entrepreneurial activity and short-term contracts created their own tensions in daily work and longterm prospects for research quality (YLIJOKI, 2003).

\section{Technologies}

When looking at the developments of the economic role of universities, one has to take into account some differences between technologies and industries. The science and technologies embedded in 'biotechnology' have distinct characteristics. Biotechnology as an industrial sector is especially science-driven and typically has a much greater need for basic research and highly educated research workforce than any other industry. It collaborates considerably more with universities than most of the other industries (see COHEN et al., 2002). The development and commercialization of human therapeutic drugs can be considered as the extreme case of science based industry (SANTOS, 2003). Also the nature and history of universities themselves and the differences in national innovation systems affect the way they interact with their external environment (BOUCHER et al., 2003; LAWTON SMITH, 2003). There are also other peculiarities to 
biomedical research that affect the universities' role as domains of public knowledge. As EISENBERG and NELSON (2002) point out, both 'public' and 'private' domain research find their territories muddied and recent academic research has seen some considerably blurring of boundaries of what constitutes truly 'public' research with broader societal benefits. On the other hand, less intuitively, private firms have sometimes acted (in collaboration with universities) in ways that are more beneficial to the public interest than research in the academic setting, which has taken on stringent patenting practices, for example (ibid.) Similarly, the controversies over legitimacy given 'risky' technologies also questioned the autonomy and supposed neutrality of university-based scientists and the quality and transparency of their scientific advice (JASANOFF, 2003). As we will show in the case study, the sectoral characteristics had a very large influence on the specifics of how Turku's universities behaved.

\section{PRELIMINARY THORETICAL FRAMEWORK: "TASK-ORIENTATION", INDIVIDUALS VS. HOLISM IN INSTITUTIONS}

Some economic institutional frameworks view institutions as rules of the game structuring incentives for human exchange and economic performance (NORTH, 1990). As others have pointed out, the 'rules' are not of equal value, especially in determining the context of university engagement in a system of innovation (LAWTON SMITH, 2003). We concur, particularly that commercialization functions are being weighted more heavily than other functions of universities. However, we take a different approach here. We question the very origins of action, strategy and goal orientation as responses to 'rules'.

A strong presumption implicit in the discussions of the Third Role and the future economic role of universities is the idea that strategy and rational-action, via leadership (or gentle or other coercion) might lead to economic results. We argue that to take this line muddies considerably various theoretical concepts such as the role of individuals vs. those of organisations and institutions that 
have practical implications for the Third Role. Can universities be thought of as single actors? Or more importantly, how do universities' actions emerge out of the actions of individuals? How are these different?

In line with HODGSON (2006), we argue that universities (similar to firms) are not only organisations, they are also institutions themselves. i.e. "generally, institutions enable ordered thought, expectation, and action by imposing form and consistency on human activities. They depend upon the thoughts and activities of individuals but are not reducible to them.' Thus, we argue that it is not simply that rules exist, but that social transmissibility is of relevance, since habits are as important as strategy in thinking about our specific case of universities.; "this is not to deny the importance of intentionality, but to regard it as a consequence as much as a cause and to place it in the broader and ubiquitous context of other, non-deliberative behaviours" (ibid., p.7). Thus, as the author has argued here and elsewhere (e.g. HODGSON, 2003), institutions do not simply coordinate behaviours and actions of individuals, they also constrain and mould them. An organisation, to be treated as a single actor, then ironically, needs a better specification of its social boundaries and rules.

As such, given the importance of the individual and the institution, we argue that the compatibility of any 'rule' (what here are the "softer" tasks of the Third Role) with local economic needs is a negotiated process, not necessarily having foresight and predictability. From an emergence standpoint, as discussed in SOTARAUTA and SRINIVAS (2006), BOSCHMA (2004) and CURZIO and FORTIS (2002), economic systems and organizations co-evolve with each other and with their environment. Certain identifiable points (times) exist at which a transition occurs and newer institutional forms emerge. Therefore, while institutions reflect this continuity and change in society, they are affected by individual actors (SCOTT, 2001, HODGSON, 2003). To better 
understand task-orientation at institutional-level we suggest that an insight into individual goals and actions may be useful, i.e. a discussion of holism and individualism (e.g. RUTHERFORD, 1994).

We take as a starting point that engagement of universities in the economy is the archetype of a process of institutional change and these emergent institutions arising from complex processes. Yet, the timescale on which institutional change occurs is much longer relative to individuals as units of analysis (e.g. HODGSON, 1988). While both "old" and "new" economic institutionalists vary in their respective schools of thought on the extent to which individual action plays a role in social change, AGASSI $(1960,1975)$ may come closest to describing a middle path in how individual action while shaping institutions, is itself circumscribed by institutional factors. Agassi's contribution is "that it highlights the impossibility of indigenizing all institutions within a theory that takes as given only the physical environment and the psychological states of individuals. In any theory that attempts to explain the development or change of some institution(s), some other institution(s) will have to be taken as exogenous...(..)". (RUTHERFORD, 1994). Thus, a normative or rational actor, goal-oriented explanation of university engagement, however desirable as an outcome, appears to be insufficient an explanation of processes on the ground, but the two types of analysis can nevertheless be linked in an analytical discourse as we show. Unexplained divergence between goal and outcome can be more usefully ascribed to the interplay, or co-evolution, between rational planning and policies (intention) and self-organizing (emergent) development (SOTARAUTA AND SRINIVAS, 2006), Yet, as they point out, a purely evolutionary approach stresses adaptation and learning, but common with most ecological studies, often tends to ignore socio-political strategies and intentions of individual actors or collectives. This is the tension explored here-between institutional formation and the link between individualism and holism.

Thus, it becomes useful, we suggest, separating out strands of this contextual analysis into (a) external economic change (b) university-level initiatives and (c) individual actors and their efforts. Without this, simply analysing universities' engagement with industry is devoid of institutional 
detail, strategy insights. For example, some recent studies show that these new interactive modes of research do not necessarily conflict with more traditional academic goals and rewards (e.g. GULBRANDSEN and SMEBY, 2002). Localised studies in Tampere, Finland, such as YLIJOKI (2003), show that individual action is still visible and that "market orientation is only side of the coin. Work researchers strongly emphasize that they do not hopelessly drift wherever the markets lead them, but instead they have their own interests which they reconcile with the project demands.....thereby creating continuity, "a grand plot" in their work.....Personal interests and market-orientation can thus be successfully accommodated. This too, is a question of research skills." (ibid.). This level of action and individual agency is set against the more abstract and normative debates about the broader relationship of state, society, market and the creation and use of knowledge (e.g. DELANTY, 2001; GIBBONS et al.,1994; NOWOTNY et al., 2001). These are important questions for university management and faculties as much as they are relevant for economic development practitioners. Without the separate strands made visible of impetus and agency, normative prescriptions for the Third Role then become largely ahistorical and difficult to translate into active policies.

We use the case study method to study Turku, Finland, because theorizing about such institutions cannot be complete unless it can draw upon systematic inductive studies of economic institutionalization as occurs in practice. Turku is the third biggest city-region in Finland and is the country's oldest city dating back to the $13^{\text {th }}$ century and the capital until the 18 th century. It is a major port with an illustrious history in academia, culture and government. Today, Turku is the second biggest concentration of biotechnology activities in Finland after Helsinki. According to ISPE (2003), Turku is one of the three centres in the Nordic countries to have above-average levels of biotechnology research and commercialisation in Europe. City-level differences certainly emerge as we will witness in the following sections. Infrastructure, uneven funding and administrative barriers to interdisciplinary research all cause challenges for Turku's universities to engage more in 
regional development, yet Turku University has performed admirably at regional, national and European-levels despite its constraints (TOMLIN, 1999). We will see next what the various strands of institutional development were that affected the university, and how individual action was woven in. Turku's story of how the universities became (to the degree they are now) institutions for economic development, thus can be seen as a way to disentangle the institutional and individual strands to the analysis.

\section{THE CASE STUDY OF TURKU}

The research focused in particular on the role of two specific universities and their involvement in the creation of "BioTurku", the city's high-tech concentration. The primary data consisted of detailed interviews and analysis of industry statistics, national, regional and city government policy documents, in addition to previous studies about the development of industrial activities in Turku with a specific focus on the policy period starting from the mid 1980s to 2004. However, earlier changes to the sector, ranging from the 1940s, were studied in some detail. A total of 36 detailed semi-structured interviews (each averaging 45 minutes to an hour and a half) were conducted over an intermittent 6 month period in 2002, with academics (scientists), policy makers at various levels, CEOs or R\&D heads of companies and actors working in intermediary organisations such as those of economic development agencies, city officials and hybrid organisations for sectoral growth. Many interviewees were officials or scientists involved in changes from the 1970s and 1980s and so we were able to witness some continuity to Turku's narrative. Quite a few of them also work or have worked in Helsinki region and were thus able to compare the developments in the two cities. Younger interviewees had been students in the region at the time and thus had their own insights. We verified data and were in contact with interviewees until 2004. We studied detailed case histories of other Finnish cities to contrast Turku's fortunes and studied documentation on universities and their regional roles in Finland from prior decades of policy and scholarship. We 
paid special attention to private sector and public domain strategy documents for various biotechnology-using sectors, such as foresight data on pharmaceuticals, diagnostics, the food industry and biomedical devices. For reasons of confidentiality agreed to in the LIS project, we use anonymous quotes here.

Today, there are approximately 60 companies related to biotechnology activities in Turku and around 3,000 jobs in the biotechnology related companies. The most important branches were diagnostics (23\% of the companies), biopharmaceuticals (18\%), biomaterials ( $7 \%$ ) and functional foods $(7 \%)$. The rest $(45 \%)$ consisted of different services. (TURKU BIOTECHNOLOGY STRATEGY, 2004). A notable part of innovations in the smaller biotechnology companies are based on university discoveries and even the bigger companies are actively collaborating with local university research groups. Finland's first university was established in Turku in 1640. It was moved to Helsinki in 1827 and became Helsinki University, the only one in Finland at the time. A less than century later, in 1920, Turku got a new university. Today, there are two major universities in the city, the University of Turku (UTU) with 17,300 students and Åbo Akademi ( $\mathrm{AA}$ ) with 7,000 students. Turku University today graduates 1,069 Master's degree students a year and it also serves 117 Doctorates a year (2003) and offers a vast spectrum of departmental subjects. UTU has several areas of excellence with world-class research in biochemistry and molecular biology, including immunology and receptor biology (BIOTECHNOLOGY IN FINLAND, 2002). Åbo Akademi (ÅA) predates UTU by two years and is a major university for the Swedish speaking minority in Finland. AA has a unique position in hosting the only engineering department in the Turku region, with the areas Chemical Engineering and Computer Engineering. Together these two universities form a substantial research community with an estimated size of 120 professors, around 50 different research groups and 600 researchers related to biotechnology activities with around $80 \mathrm{PhDs}$ graduating every year (TURKU BIOTECHNOLOGY STRATEGY, 2004). 
Overall, the level of scientific research in Turku's universities has been high with many research groups near the top of the world in their related fields. The combination of skills in engineering and chemistry within $\AA$ A and the biological ones in UTU have allowed expertise across fields of basic investigations relevant to medical therapeutics, diagnostics and biomedical devices. In addition, Å's specialties in chemistry and biochemistry and food chemistry in UTU have obvious implications for the food industry. In addition, for research in biotechnology and informatics, close collaboration and university support goes towards individual institutions such as the Turku Centre for Biotechnology, the national PET-Centre and the Turku Centre for Computer Science. Importantly for the pharmaceutical industry, the University hospital continues to build up a force in basic research as well as clinical study and testing services. It also provides an important source along with the medical faculty of the university, of validation of early drug target research in the private sector.

With this long academic and historical tradition, it is perhaps unsurprising, therefore, that in contrast to other Finnish cities a long tradition existed within Turku's universities to emerge as national as opposed to purely regional-level institutions. For example, the Tampere University of Technology was designed to be "a university for industry" from its inception in the 1960s and had a very strong regional focus. The same was true of many smaller universities in Finland that were established on regional policy grounds.

\section{THE CHICKEN AND EGG PROBLEM: WHO BEGAN THE PROCESS OF INTERACTION?}

Understanding how and when the university has come closer to industry today requires a closer look at the organisational and institutional landscape of the city in earlier times. We argue that there is no neat, normative answer to which agents built this concentration. In Turku, it has arisen through a complex process of economic institutionalisation and with no clear strategy or goal orientation at 
the outset by policy makers or academics, universities or firms. Instead, based on our research data, and keeping with an evolutionary approach of selection, we highlight the intertwined nature of six separate strands of institutional growth, selection and linkages, most of which were accompanied by resource constraints and pressures to collaborate. We begin with those that had most in common with other regions in Finland, and then move progressively to more regionally-specific details.

- the state-driven model

- older companies and their university-oriented push

- recession and crisis

- the rise of regional development initiatives

- individual mobilisation

- the reappearance of universities with a muffled regional mandate.

While the six strands capture the institutional process, there has been a process of economic selection ongoing as well. We argue that in Turku, selection on university response and firm capabilities has acted in three major ways: (a) through national economic recession affecting all Finnish cities, it has limited Turku's choices, further complicated by Finland's EU accession in 1994 and its impact on the pharmaceutical sector (b) through global mergers and acquisitions specific to the pharmaceutical industry, which has created significant concentration in Turku, and (c) through international changes to the science of biotechnology which has shaped local paths of firms and university departments. Thus there were dominant pressures to form new coalitions and new collaborations spurred more by external economic forces than internal political ones and the process of institutionalisation of a new university role (the Third Role) has emerged for a different set of reasons than that which is normatively discussed. The transition to such institutionalization can be seen in terms of shifts in selection environments, each further pushing the universities to seek local alliances and resources. Turku is thus less "new" in terms of its emergence and more intentional through the creation of a new identity (see also SRINIVAS and VILJAMAA, 2003). 
The development of the biotechnology industry in Turku has, in many ways, been connected to changes in the national policy environment that shares similarities across Europe. Compared with some major biotechnology concentrations in the USA and the UK, the Finnish national policy push is highly integrated but remarkably state-visible (e.g. COOKE, 2002). There has even been a discussion of making biotechnology the 'fourth pillar' of the Finnish industry in the future (see SCHIENSTOCK and TULKKI, 2001) and as an indication of this strategy, biotechnology has been one of the key areas of public funding and institutional support during the past decade. As with other European countries, most of the financing for the universities and the companies come from public sources and there are several dedicated programs at the national level to support biotechnology. In 2001, the government funding for biotechnology research was $€ 142$ million and the biosciences cover roughly $40 \%$ in the national R\&D budget. The biggest sources of funding were the Ministry of Education (36\%), The Finnish Funding Agency for Technology and Innovation TEKES (28\%) and the Academy of Finland (28\%). Ministry of Social Affairs and Health and the Ministry of Trade and Industry also participated in funding (HERMANS and TAHVANAINEN, 2002). The national technology agency TEKES has invested some $\$ 90$ million in biotechnology, which accounts for $27 \%$ of the total investments. The Ministry Education, on the other hand, has set new Centres of Excellence (university units with extra competitive funding) to universities and in 2000, nine of the 26 top units were in the field of Biotechnology.

Three national level public organisations, the Academy of Finland, TEKES and Sitra stand out. The Academy of Finland and TEKES were, and continue to be, influential supporters of research and education. Sitra was crucial in providing financing for the new start-ups in the absence of private venture capital companies in the 1990s. There are also national programs like Centres of Expertise co-ordinating and focusing resources in key industries in many cities, one of which is in Turku. One of the key areas in the Turku Centre of Expertise programme 2000-2006 is related to biotechnology. 
The strong role of the state is visible locally as well in the two main research universities, even if its influence on Åbo Akademi emerged later. Universities gain their funding from three primary sources: budget funding, earmarked funding, and competitive funding. The budget funding by the Ministry of Education for biotechnology research in 2001 was 3.94 M€ million for the UTU and 1.22 M€ for Å. In addition, the Ministry of Education and Academy of Finland provided 39 M€ of biotech funding to research, researcher posts, researcher training, Centres of Excellence and international activities in Finland in 2001. This money goes to a great extent to various biotech centres like BioCity Turku. Moreover, TEKES provides 22.6 M€ of competitive funding to Universities and Biocentres nationwide. (BIOTECHNOLOGY IN FINLAND, 2002) Table 2 below represents the division of the Academy of Finland and TEKES funding for Biotechnology in 2001.

\section{\{Insert Table 1 here $\}$}

Important tools for biotechnologies are the nationally-supported graduate schools, Centre of Excellence funding and the Academy professor posts. In 2001 there were, for example, 20 Graduate Schools nation-wide with 280 student positions schools in areas connected with cell and molecular biology and biotechnology in Finland. Seven of these schools were co-ordinated by the UTU or ÅA. Of twelve biotechnology related academy professors, two are working in Turku (in BioCity). In biotechnology, there are 18 different labs or departments that were granted a Centre of Excellence (CoE) status. Two of them are in BioCity (BIOTECHNOLOGY IN FINLAND, 2002).

However, the strong presence of the State in supporting biotechnology has recently seen some signs of weakening. Biotechnology has not met the growth expectations and hopes of becoming the next breakthrough industry after the successful ICT boom in the 1990s. The biggest public funding institution Sitra has been slowly withdrawing from supporting biotechnology, Tekes is reevaluating its policy concerning biotechnology and the ministry of Trade and Industry is also considering new alternative ways of supporting bioindustries. During the past few years there has also been a lively discussion in Finland on how to make the investments in biotechnology more 
productive in the future. There has been, amongst others, discussion that too much emphasis has been put on science and tool little on business development. Some new studies address that the support for biotechnology should be more focused in the future for only a few selected key areas. Despite all these recent pressures to the current state-driven model for supporting biotechnology it is still a fact that state has played a remarkable role in building biotechnology capacity in Turku. Yet, despite these common traits within the national system historically, we see some unique turning points in Turku's history, some of which were reviewed in the discussion on recession. Next, we look at Turku's unique regional development profile.

\section{Older companies and their university oriented push}

The background of the biotechnology industry in Turku and in Finland can be traced to the development of the domestic pharmaceutical industry, born in the late 19th century. The exercise of autonomy, the acts of strategy, and the coalition-building of many local actors (but not the university) needs to be understood against this backdrop of older capabilities and the impact of the late 20th century economic recession. What the data shows is that there was nothing "natural" about today's relationship between university and industry. As a city under considerable economic pressure Turku was forced to face up to an uncertain future.

The first important turning point for the city occurred in the 1940s, when the first pharmaceutical companies Farmos and Leiras, started research and development bases in Turku. One of the companies had a founder from the region that was familiar with advances in research communities of the universities; another situated itself there primarily to exploit a relationship with the universities. In both cases, it appears that companies sought out the university and tapped local capabilities. Thus, aside from the universities, there was an established pharmaceutical industry base in the region. There are two large pharmaceutical companies present today, Schering and Orion, both of which do R\&D in Turku with a few smaller drug discovery companies today like 
BioTie Therapies, Hormos Medical and Juvantia Pharma. Most of the smaller companies have appeared during the past ten years and the number of companies has increased rapidly. There are also several companies working in the field of diagnostics. The most notable is PerkinElmer-Wallac that produces measuring devices, software and reagents for the research and development of drugs and diagnostic systems. Many of the smaller diagnostic companies are either spin-offs from Wallac or related to it in some ways e.g. Arctic Diagnostics, whose founder was a long-time R\&D manager in Wallac. There are also some small companies that are spin-offs from the university.

Turku's mid sized companies Leiras, Farmos and Wallac, established the tradition of co-operation to some university groups and departments during the time when it was not that common in Finland. They also had a need for a steady supply of professional employees. PE-Wallac, in particular, seems to have institutionalised many of its interactions with university researchers, and this culture seems to have been copied or at least supported, by researchers within other companies. While the larger, older companies had some obvious gains by coming to the university, they have themselves contributed to the development of the university research and that of smaller firms and have thus been a valuable asset for the regional concentration to build on. The bigger companies (a) created specialised expertise in business and development activities now accumulated in the region, (b) contributed skilled labour: many key people in the smaller companies in Turku and even in the universities have worked in the bigger companies and (c) acted as a pool for new start-ups. Many ideas have been exported even by individual workers leaving the company but in some cases also by a dedicated spin-out strategy of the bigger company (d) acted as a minor source of special services.

In Turku there also seems to have been less resistance in the university to applied research and cooperation with companies and this was propelled by largely industry-initiated interactions. It is a widely shared view, that co-operation was already quite normal in Turku at a time when in universities elsewhere, and in the Ministry of Education (especially in the 1970s), co-operation with 
industry was viewed as not relevant to the cause of the university. Stressing this dynamic linking of old pharmaceutical firms with the local universities, one respondent said,

\section{“...key founders and key people in these pharmaceuticals whether on Board of Directors or} in advisory capacities, have been professors. In the 1970s there was a university backlash to make research "pure", but in Turku it never seemed to cut off the very significant ties to the three main companies. So in Turku there were hundreds of people in $R \& D$, mainly in biosciences linking University with industry.”

Even in Turku, despite patchiness in the relationship between university and industry, not all departments reacted the same way and some were less recalcitrant than others. For example, in food more than in medicine, there seems to have been less resistance overall to working with industry, since $\mathrm{PhD}$ students themselves in food chemistry are exposed to industry early on in apprenticing through their educational years.

If we had to pinpoint what the larger companies have contributed towards the local constellation of innovation, it has been as a source of people with ideas and past interactions with the university. While the interactions with academia may have been institutionalised to different degrees within the different companies, every company effectively passed on a tradition to the region for hiring in university researchers, or for having in-house corporate researchers with an open attitude to working with universities.

But these companies are unlikely to have forged such strong local identities over time without the impact of economic adversity. As described next, Turku developed somewhat luckily, as a base for Leiras (of the Schering-Plough group), and Farmos (later fused with Finnish pharmaceutical company Orion), both in drug development, while Wallac was acquired by PerkinElmer to become PE Wallac for the diagnostics industry. Thus, Turku went from a city with an early concentration of 
therapeutics and diagnostics to one explicitly driven by the dynamics of two multinationals and one large domestic company.

\section{Recession and crisis: the national and regional development process}

Table 1 below shows the chronology of the development pressures that Turku faced. The local landscape remained relatively uneventful until the 1970s heralded the advent of more global relations and increased trade with other countries. However, the same global relations also created instability. With the fall of the Soviet Union and the lucrative soviet markets, Finland and Turku, in particular, faced significant hardship and economic recession. The period from 1990 to 1999 proved to be decisive for Turku. Unemployment in the city rose from $4.2 \%$ in 1990 to $22.1 \%$ in 1994 . The food processing industry alone lost $21 \%$ of its labour force. Despite its best efforts through combined public and private strategies, Turku unemployment in 1999 was still $17.4 \%$ compared with the Finnish average of $10.2 \%$ in the same year. However, Turku stood to gain by some unexpected outcomes of other global changes.

\{Insert Table 2 here $\}$

Significant global mergers and acquisitions in the pharmaceutical industry created a series of conditions wherein Turku was left with Finland's highest concentration of therapeutic and diagnostic firms and two new multinational companies, along with a residual sizeable, but vulnerable, food industry ${ }^{1}$. The pharmaceutical sector in particular lost large markets in the fall of the Soviet Union and then global mergers and acquisitions wrought major changes. Further global integration and the 1995 Finnish accession to the European Union, created both gains and setbacks for the rapidly shifting intellectual property regime facing homogenisation and the need to move into newer areas of $R \& D$. 
The role of cities in re-engineering their futures took on greater urgency as the State battled recession on multiple fronts. However, compared with other cities in Finland like Oulu and Tampere, Turku thus became active in proactive local economic development policy quite late. This was partly a consequence of the local industrial structure; Turku did not face industrial crises as severe as those confronted by Tampere for example. But in the 1990's the national recession and fiercer global competition resulted in a slow decline in its economic base. Traditional industry sectors such as ship building, machinery and the food industry were slow or even stagnant in their growth compared with sectors directly built on information and communication technologies. In the absence of large ICT-sector, attention in Turku turned to the emerging biotechnology cluster. Indeed, its lack of an ICT base allowed it to find a new identity in a "high-technology" arena by merging various sub-fields of $\mathrm{R} \& \mathrm{D}$ using biotechnology such as food, materials and pharmaceuticals.

\section{Reacting to the Centre: the rise of regional development initiatives}

The impact of the changes in the national science and technology policy has been very remarkable in Turku. The amount of public funding both for the universities and the companies has increased significantly especially during the 1990s. However, this change cannot be seen only as a result of the changes in the national innovation policy but also partly as a consequence of local initiatives, which have arisen gradually with involvement from the city council.

An external factor of considerable importance in the inspiration and evolution of Turku biotech seems to have been comparisons made by locals, and by national policy makers, of the differences of Turku with Helsinki. The delayed local introduction of State Research Centre (VTT) is a case in point. Turku remained quite invisible (compared with Helsinki for example) until the late 1980's. During that time (1987) the Ministry of Education launched a new research programme on biotechnology. In the first drafts were very Helsinki-centred despite the fact that Turku was not 
much smaller in terms of biotechnology related activities. This 'injustice' raised local activity among the research community (BRUUN et al., 2001). This situation leading to local informal initiatives to increase the visibility of Turku in terms of biotech activities can be seen as one of the turning points in recognising the opportunities to develop a local concentration of biotechnology.

The visibility of Turku's city officials emerge in the first deliberate steps in recognising the new opportunities from the mid-' 80 s when the first dedicated project for improving biotechnology research (the South-West Finland Biotechnology project) started. In addition to scientific results, this can be seen as the first time when biotechnology was introduced as potential growth area. Approximately at the same time (1986) a Foundation of New Technology (FNT) was established. This was an informal organisation, consisting of around 30 key people mainly from industry and academia and originally intended to discuss about plans to establish first technology park idea the Data-City (BRUUN et al., 2001). FNT was the first bigger forum where key people could be brought in to the development process.

The technology centre that started to take shape in the late 1980s was the physical forum for building a cluster. Technology centre BioCity from 1989 onwards was the second stage of the local technology park concept. Earlier positive experiences in starting an ICT related activity in the form of DataCity gave the actors more confidence for pursuing same kind of activities related to biotechnology. The universities saw that co-operation between them could work and the local decision makers were more aware of the new opportunities. The recession in Finland in the early '90s activated also the city government to look for new future industries to concentrate on. One interesting factor was the role played by real estate business, which was actively involved in developing the BioCity concept from the very beginning.

BioCity was not only a building for companies to operate but also a bigger concept. The idea was to provide links between industry and academia by gathering a critical mass of researchers in different 
fields along with technical resources and possible company partners (BRUUN et al., 2001). This was accomplished by establishing new facilities, particularly laboratories that were jointly administrated by the University of Turku and Åbo Akademi. From the universities point of view, however, our interview data shows that this new kind of organisational innovation came not so much from a shared vision but from lack of resources, which made the administration look for new ways of co-operation. As a result of the cutbacks in public expenditures during the recession the universities faced a $16 \%$ decrease in budget funding in 1993-1994. Even after that period, the increase in budget funding has been only modest while more responsibilities have been assigned to universities and the number of students has increased rapidly (NIEMINEN and KAUKONEN, 2001). At the same time, external financing for the universities has grown rapidly. For example at the UTU the relative share of external funding rose from $8.8 \%$ in 1985 to $34.5 \%$ in 2004 and $\AA$ A from $2.9 \%$ to $37.0 \%$ during the same period. This change in the funding structure led universities to find new models for research and teaching. In Turku, one way to arrange this was to establish new forms of hybrid organisations, like the Centre for Biotechnology. As interviewees noted:

"Some of these departments are very expensive, so they [Å] have linked up with the University of Turku for the Centre for Biotechnology by necessity” and

"Universities are part of the broad privatization push and in general keeping with changes in Europe, therefore must get outside funds."

Local actors have been active in using the opportunities provided by national science and technology and regional policies, like the national Centre of Expertise programme. One element that shouldn't be underestimated has also been the use of biotechnology as a spearhead branch in “city marketing". 
While the regional development initiatives were growing, individual researchers had been active for quite some time, first with older companies, then within university departments dealing with the "new" biotechnologies.

Individuals versus institutions, or institutions driven by individuals?

While the initiative to link up with industry may not have existed formally within the university, it has existed strongly on the parts of individual researchers, who have been important players in galvanising academia, industry and policy makers alike, into recognising the importance of biotechnology for Turku. This is recognised even within the university system. As one university interviewee put it: "The University was not the prime driver, but scientists were" However, even with individuals in the university making a push to support biotechnology research and collaboration, the spectre of resource constraints does not disappear:

"A few people at university were interested, but more in their own self-interest to get research funding”.

A fairly small but active network of individuals appears to have had a big effect not only on improving the competitiveness of new pharmaceutical companies but also on mobilising new policy activities to support the local cluster's development. For example, the companies such as PE-Wallac were certainly important factors in this internal culture driving later industry-university links in Turku and were often driven by the initiative of motivated individuals within PE-Wallac. Individuals with histories in big pharmaceuticals as well as other leading firms have pushed the boundaries of university links. These people have been as likely to be institutional drivers in the early years as have organisations. ${ }^{2}$

In the best instances of individual linkages, researchers and company executives know each other personally and there is "no need to reinvent the wheel", as one company interviewee said. For a long time, the mobilising of local resources and the attempts to influence national S\&T policy have 
mainly been a result of an interaction between individuals working in both the industry and in the universities rather than a general strategy of the universities or the local government. For example the whole BioCity concept has originally started from this kind of a voluntary interaction. At the same time universities as organisations were lacking a conscious strategy concerning the development of biotechnology. A local policy maker summarised the views of many others in the profession: "The University doesn't have any clear idea of what to do with biotech". From a spatial standpoint as well, the universities seem to have been followers, not leaders. University-based individuals galvanised the initiative, but the institutionalisation of this initiative has been slow to occur.

"It always starts with individuals, then somebody develops infrastructure etc. On the organisational agenda as well, biotechnology has been less visible. For example the universities have not been very active in pushing a dedicated strategy about how to develop biotechnology.”

Nevertheless, while informality of interaction initiated by some individuals has some obvious advantages, there has been concern expressed by a variety of interviewees that the local network of active individuals is too small and that too much of the burden is laid on few key individuals. As one company CEO said:

"At the early stage it is useful to network and later on becomes cumbersome and begins to be inefficient for many. There are too many competing interests on time for organizations. It may still be useful for the University, but for firms there is competition to prove results, so they are overworked and frustrated."

In this way the recently strengthened position of the City of Turku and new organisations like Bio Valley may help to further institutionalise the activities, which previously were more likely to have been sustained by individuals. Some interviewees did suggest however, that too much formality 
saps the inherent strengths of the interactions and places too much time-pressure on individuals with designated positions in the formal institutions.

Thus, while individuals had played an important part in building bridges with industry and galvanising greater efforts related to the 'tasks' of the Third Role, the universities had been slower to institutionalise these efforts and build on them. This is now changing in different ways and will need time to assess.

\section{The university (re)appears with a muffled regional mandate}

In Turku, "older" biotech has merged with newer forms, and the strengths of the last 50 years still define current competencies and reputation. For instance, Åbo Akademi with its organic and inorganic chemistry expertise has allowed past expertise to bear fruit in a "newer", high-tech mode. These departments which had early-on established a reputation with industry by working on relatively mid-tech problems (by today's standards) with industry (such as in wood processing and pulp and fibre chemistry), now find themselves with new opportunities in a convergence of fields many of which have since gone "high-tech" in biomaterials, functional foods, diagnostics and therapeutics. Furthermore, a State-driven push to initiate greater university-industry dialogues has resulted in more funds for resource-needy researchers to engage with industry, but resulting in a mixed picture in terms of outputs and institutionalisation of publicly-funded knowledge for regional development (SRINIVAS et al., 2005).

While it is challenging to quantify these differences between the firms and university behaviour in Turku versus Helsinki, the comparisons with the capital are evident in the interviews. For example, one university administrator said: "The old universities have been conservative and have also had easy money in Turku, whereas in Oulu, Tampere, Kuopio, universities are more politically flexible. Here they will still tell you that the university can do without the city. Here the origins of the universities have meant little ties with the city. It's a very conservative town." Another researcher 
said: "In 1970s there was a negative trend towards industry in Helsinki and elsewhere, but this was not so in Turku, which had good cooperation, university faculties doing a lot of research for the two pharmaceutical companies." Finally, there was some hint that the university administrations themselves might deserve closer investigation across the cities, as captured by a university researcher: "The administrative culture in Helsinki relies more on formality, Tsarist hierarchies, perhaps emanating from Russian history".

Overall, the comparison between universities in different cities and with different technical missions warrants further investigation regarding their timing in ostensibly and practically taking on a Third Role. The technical universities were very collaborative. In Tampere for example, the Tampere University of Technology has been particularly active in building external engagement with the local industry. Yet, the University of Tampere, with a different mission (less engineering to start with) has been historically more conservative in its relations to the city and to industry, but is nowadays considered more flexible. Helsinki University on the other hand, has been considered possibly the most conservative in terms of external relations and collaborations, but even they engage in many collaborations today.

A further recent boost to industry has occurred in modern biotechnology with strong academic linkages to the US. When the molecular biology revolution occurred in the 1970s, many PhDs and medical doctors from Turku did their postdoctoral research work in some of the best laboratories in the US. During they stay they witnessed firsthand the birth of commercialised biotechnology and the many pathways through which academics became involved in the business of medicinal biotech. A few lead researchers subsequently returned to Turku and became intricately involved in the setting up of both research centres as well as a start-ups and paved the way for a new approach to interacting with industry.

Today the landscape is considerably changed, with the universities linked to each other and to firms in a more explicit mandate for regional development. The Centre for Biotechnology (CBT) is a 
good example of this co-operation. It is a dedicated university research unit that was established in co-operation between both Universities. The Centre has three major functions: research, training and education and it provides technical expertise and coordinating services and equipment for academic and industrial projects. The Centre has also provided a forum for active interactions between academia and industry. In addition, a great deal of university research is conducted by organisations outside the universities, such as those under "BioCity Turku", an umbrella organisation mandated to structure collaboration, resource sharing and infrastructure development in research and education with a community that consists of over 50 research groups and over 500 people working mainly on cell and molecular biology and other biotechnologies.

Acknowledging the importance of spatial configurations, Turku Science Park (TSP) is the hub of biotechnology innovation and is laid out in a small area abutting the city downtown area next to the campus areas of the two universities. The rabbit-warren architectural frame encompasses a dense setting of corporations, university laboratories, public sector S\&T, venture capital agencies as well as common restaurant and café facilities with low barriers between the industry and academia. The goal of the TSP, through organisations like Turku Bio Valley, is to provide support for the entire 'innovation chain' from invention to production through the "branded" concept, or shared vision of a "BioTurku", a new conceptualisation of a high-tech Turku region.

\section{DISCUSSION: TASK-ORIENTED INSTITUTIONALISATION}

We began the paper by asking (a) what persuades universities to become involved with an economic development mandate and (b) what persuades universities and industry to work together. Normative prescriptions for task orientation in economic development assume specific strategy and goal orientation. We have only been able to briefly sketch for reasons of space, the six institutional strands of history which are intertwined, but show the level of external influence, university engagement and individual action. We find that universities' intent to collaborate in Turku has been 
driven mainly by resource constraints over many periods broadly arising from economic recession and the gradual retrenchment over recent decades of public support forcing a shift by policy-makers towards more 'entrepreneurial' views of universities. While these were not specific to Turku, we showed rather than a consistent strategy of local engagement, Turku's universities were differentiated from others by two main features that were sectoral and regional in their impact on university and individual behaviour. First, a unique set of technical specialisations developed over a few centuries in Turku. These were shaped subsequently by the impact of global mergers and acquisitions on the large pharmaceutical and diagnostic component in Turku's base and the uneven local impact of larger economic shifts due to the recession and shifts in intellectual property regimes, and the loss of the Soviet generic drugs market. Secondly, a specific regional history and $\underline{\text { identity }}$ of Turku as former capital city vis-à-vis today's capital Helsinki and the actions of Turku's actors to shape outcomes in accordance, have had a specific influence. Both of these, sectoral and regional, features were in turn affected by resource constraints sweeping Finland and much of Europe, forcing the city's universities to interact with industry and broader regional development initiatives in unique ways.

Fundamentally, Turku history shows that there were few obvious examples of university-initiated projects to work with industry that have not had as their basis a financial or infrastructural resource constraint. It is true that the initiative to link up with industry has existed strongly on the parts of individual researchers, and in a small city like Turku, key individuals (despite the lack of strategic support from their own institution) have become important drivers for change in their own right. Nevertheless, the reality is that the universities were unlikely to be pioneers in venturing offcampus unless resources (financial or infrastructure) forced them to. The interaction has been primarily driven to varying degrees by large pharmaceutical and diagnostic companies in the past and by individuals within them. More recently this function has been taken over by start-ups and spin-offs, some of them generated by the consolidation of R\&D within the larger companies. 
Therefore, although the universities have recently taken a more active role with external engagement (see GODDARD et al., 2000; 2003b), this appears mainly to have been a result of external influence by firms, national policy and local informal coalitions and not a result of conscious strategy by the university administration. This is an important finding that fundamentally challenges the way we normatively think of the universities' role, and when and how we anticipate 'task-oriented' institutionalisation to appear.

In the conception of institutional change of new economic institutionalists, the individual has an important role to play, while this is downplayed although certainly not absent, in "old institutionalist" perspectives. Here, while institutional change to new economic roles has certainly been influenced by individual response and intention, the reality is that the university's overall response has been a process of collective sense-making of changed circumstances and of successive selection within the city. Emergence underscores the idea that global economic structure has significant elements of local interactions and thus actors both create their environment and adapt to it. Universities thus cannot be seen to be central agents driving change, but as institutions that have benefited and evolved from broader changes, i.e. they have co-evolved with development, but have been structured by specific transitions (SOTARAUTA and SRINIVAS, 2006). The influence of individuals may be less important and their time-scales of action short. Thus emergence provides an insight for economic development compatible with old institutional economic viewpoints which take this into account. This is a far cry from an entirely rationalist, strategic frame for economic development planning since individual actors cannot fully analyze their own environment and thus design optimal strategy. In keeping with Axelrod's framework, actors in Turku reconcile their strategies to successful ones of the past and by observing what others are doing. However, this is no endless repetition of strategies as actors are forced to reconcile their actions with a changed selection environment of the three types that Turku has witnessed, and thus give rise to new forms of institutionalisation. Indeed the processes of economic institutionalisation as phenomena, we 
argue, must arise through inductive studies of the sort we have conducted where the normative debates of the "Third Role" are linked to the positivist tradition.

Thus, Turku's evolution may be less a case of posing individual action against holism, but to suggest that more collective sense-making and economic action (e.g. commercialisation of R\&D, acknowledgement of university contributions to the region) has emerged over time. In effect, holism rather than absent before, may have become more visible as the processes of economic institutionalisation of the university has taken hold and captured the imaginations of citizens. This has occurred because of dramatic exogenous shifts in the economic environment and changes in the technological make-up of local biotech-related capabilities, which have shaped individuals' (particularly those in universities) interpretations of local resources, institutions and their own engagement in creating a different future.

A newer role for the university may be emerging, with smaller firms having been cut off from large internal corporate $\mathrm{R} \& \mathrm{D}$, opening up new channels of communication with the universities. Biotechnology SMEs are also often specialised in R\&D rather than production and distribution, and face serious financial and product deadlines, less space for leisure. These infuse their collaborations with universities with some urgency. If local universities cannot provide this vision and some strategy that is useful to local firms, then the latter are likely to look elsewhere for such alliances.

Turku's universities have come to this economic development process later than other institutions such as city government, and as such have moved from an identity of a diffuse economic institution to a broader set of "task-oriented" institutional processes including regional economic development. This in turn has changed how national policy-makers and other actors view economic development in Turku and its universities. Universities as Turku's local institutions have structured a new, and still negotiated, set of rules for economic interaction. The institutionalisation is not new in terms of capabilities, nor is it exclusively 'high-tech'. Cognitively and operationally, this has meant a new language by many university actors to describe the emergence of a "new" high-tech cluster arising 
from the ruins of the recession signifying a transition to new forms of economic engagement. Turku's 'newly innovative' identity has thus been the result of collective re-interpretation and taking stock of existing resources (SRINIVAS and VILJAMAA, 2003). This alone is a significant developmental change and an emerging local strength.

We suggest five preliminary hypotheses regarding the Third Role for future regional and urban planning and policy. We limit our hypotheses to university-industry interactions, the one facet of the Third Role that we have focused on in this paper.

\section{H1. Individuals vs. Institutions:}

From our case above, the data suggests that a primary research agenda for Third Role and university-based research is to elucidate "task-oriented institutionalisation", specifically institutional formation and the different strands of individual vs. institutional effects on economic development. One hypothesis is that the Third Role for research-intensive universities historically emerges from individual action and rarely from a university-wide organisational mandate. This may be true for multiple reasons. However, we can further hypothesize for future studies that in the case of research-intensive universities that explicitly begin with a regional development mandate; this reflects broader effects of the time (such as land-grant universities with explicit agricultural or other missions such as defence research during war years). By posing individual vs. institutional action, we should then be able to develop a typology of university-types, their regional impact, and more importantly, the origins of that impact. Appropriate metrics would thus become necessary to separate (where possible) strands of individual vs. university-wide action, and how in many cases, one led to the other. The transition is worth further understanding. This is the challenge ahead for university and Third Role research as well as for planning practice and policy.

\section{H2. Pace of industrialisation-led technological change, and changes in welfare systems}

The findings from this case study can be generalised to some extent across Europe where public sector retrenchments and economic crises have occurred, and where deep sectoral technological 
specialisations have existed. In some places, universities' roles have been partially tied to welfare services and to being nationalised. It is worth asking whether and how rapid industrialisation and technological changes in Finland forced universities to take on new roles in contrast with other countries where university-state-industry-citizen relations have perhaps had longer timeframes to evolve. These may give rise to different types of Third Role interactions and accordingly shape policy possibilities going forward. This is especially relevant for countries and regions that are still industrialising in Asia, Africa and Latin America. There, industrialisation's momentum has often been driven by national policies, and the role of universities as urban and regional institutions is much less clear, yet faces urgent challenges.

\section{H3. University-specific missions and leadership}

Following from the first hypothesis, we argue that there is a need for studies on types of regional engagements that bring out the varying economic development paths that universities have. This follows from Hodgson's (2006) distinction that since organisations are institutions themselves, we need more information on the internal dynamics of the organisation to specify "organisations as social systems with boundaries and rules" (ibid.) and these are largely shaped by the changing ideas of national and local public welfare (H2.). Thus, a useful point based on both $\mathrm{H} 1$ and $\mathrm{H} 3$, is to understand how individual action from within the university influences its social role, and the ways in which it constrains and enables behaviour at the level of the organisation. Thus universityspecific mission and leadership emerge not as stand-along policy concepts, but in our preliminary framework, as a means of understanding individual vs. institutional (and organisational) behaviour and impact.

Future studies can focus on single country, single sector and different cities, or different universities in the same city. This is compatible with research emerging from the LIS study. A related hypothesis (distinct from $\mathrm{H} 4$ below) is that to the extent that cultural specialisations also exist (regional arts and culture, for example, or technologies specific to the region-such as forestry 
devices) these may shape university missions in different ways from those universities dealing with more generic technical specialisations that are perhaps more globally mobile.

\section{H4. Sector-specific (and technology-specific) Third Roles}

From Turku's case, it is worth further investigation of the links between the third role function and sector. One argument is that the universities are likely to have built regional expertise over time, and so along these oldest specialisations, the depth of university-industry interaction by the individual and department level is likely to be strongest, thus allowing university initiatives to follow.

\section{H5. Capital vs. Non-capital city-regions vs. "less-favoured regions"}

It is also contingent on future research to see whether in countries with centrally co-ordinated innovation policies, non-capital city-regions have substantially different third role histories and policy options than capital cities. These can offer new insights into how urban institutions mould local histories and why, whether and how planning at city-level substantially alters regional economies. Where 'urban-bias' has been argued in much of the development literature for nonWestern societies, the question is whether technology policies can truly act as an equalising vehicle between significant urban-rural disparities. What these institutions look like, and how they can be 'tasked' with economic development, remains to be seen.

\section{CONCLUSION}

Overall, Turku is a prescient case for broader changes sweeping Europe advocating a "Third Role" for universities. It shares many characteristics of other small to mid-size technology-intensive urban centres. Yet, its capabilities have developed over a long period, and nurtured by a variety of actors. Universities cannot be expected to automatically or painlessly deliver on a broader regional mandate via a Third Role. These sub-sets of 'tasks' for economic and regional development are substantially different from those of teaching and research, the time-scale for such institutional 
change is slow, as we have shown, and may not arise because of Third Role specifications, but instead in unique ways shaped by regional histories. The process of into conversion to an economic development and its origins need further study. This study shows that generic "Third Role" prescriptions for university-industry collaboration are unhelpful; the specific dynamics of institutionalisation and the origins of strategy and goal-orientation need to be understood on a caseby-case basis to construct any useful broader theoretical and policy framework for institutions and economic development.

Acknowledgements - The authors are very grateful to the many interviewers in Finland for their patience and willingness to share their insights. This study was conducted as part of the Local Innovations Systems project (LIS), where both the Massachusetts Institute of Technology's (MIT) Industrial Performance Centre (which led the effort) and the Tampere University Regional studies group SENTE in Finland played central roles. A previous working paper version of this research is available through the Local Innovation Systems project at MIT. The Finnish portion of this study and support for K. Viljamaa came from the Finnish Funding Agency for Technology and Innovation TEKES and the Academy of Finland. S. Srinivas wishes to acknowledge funding and logistical assistance from the MIT Industrial Performance Centre for Finnish data collection, funding by the STG Project at Harvard University’s John F. Kennedy School of Government, and a United Nations Industrial Development Organisation (UNIDO) Fellowship. These sources of support are gratefully acknowledged. We thank our colleagues and various audiences, and we benefited from very useful comments by three anonymous reviewers.

\section{NOTES}

\footnotetext{
${ }^{1}$ In therapeutics, in the 1980s, Orion Corporation and Huhtamäki Ltd. aggressively bought out most other companies, including Leiras subsumed into the Huhtamäki Pharmaceuticals Company in 1986. A further consolidation took place with Farmos and Orion being merged in 1990, and
} 
separation in 1992, with Leiras emerging as a separate legal entity once again, but being subsequently acquired by the global company Schering. In diagnostics, the Finnish firm Wallac, with a long history research and university involvement in Turku, was acquired by US-based Perkin Elmer Inc.

${ }^{2}$ For instance, researchers like Professor Erkki Soini, formerly a long-time senior researcher in PEWallac, always kept links to university research, having come from there himself. During his 20-30 year tenure at PE Wallac, he actively coordinated with university departments because he had a vision of what joint research could accomplish, and believed this at a time when few others had such a vision. He then returned to the university as a full professor, having decided that he could pursue some types of research more effectively in the university, and began his own company. (From communication with Prof. Soini and with other interviewees.) 


\section{REFERENCES}

AGASSI, J. (1960) Methodological Individualism, British Journal of Sociology, 11, pp. 244-270 (September).

AGASSI, J. (1975) Institutional Individualism, British Journal of Sociology, 26, pp. 144-155 (June).

ANTIKAINEN, A (1980) The Regional University. Publications of the University of Joensuu A 16, Lappeenranta.

ANTIKAINEN, A. (1981) The Regional Impact of Universities in Finland. Higher Education, July, Vol. 10, No. 4., 437-448.

ANTIKAINEN, A. and JOLKKONEN, A. (1994) New Universities, Welfare State and Markets, the case of Finland, in DAHLLÖF, U. and SELANDER, S. (Eds) New Universities and Regional Context, papers from an international seminar held at Sundsvall, Sweden, 14-18 June 1992. AROCENA, R. and SUTZ, J. (2000) Interactive learning spaces and development policies in Latin America, DRUID Working paper 00-13, Department of Business Studies, Aalborg, Denmark.

AXELROD, R. (1997) The Complexity of Cooperation: Agent-Based Models of Competition and Collaboration, Princeton studies in Complexity. Princeton University Press.

BENNER, M. (2003) The Scandinavian Challenge: The Future of Advanced Welfare States in the Knowledge economy, Acta Sociologica, Vol 46 (2), 132-149.

Biotechnology in Finland, Impact Of Public Research Funding And Strategies For The Future Evaluation Report 2002, Publications of The Academy Of Finland 11/02

BOSCHMA, R. (2004) Competitiveness of Regions from an Evolutionary Perspective, Regional Studies, Vol. 38.9, pp. 1001-1014

BOUCHER G., CONWAY C. and VAN DER MEER E. (2003) Tiers of engagement by universities in their region's development, Regional Studies 37, 887-897. 
BRUUN, H. (2002) The Emergence of a Regional Innovation Network: A Process Analysis of the Local Bio Grouping in Turku, Finland, in SOTARAUTA, M. and BRUUN, H. (Eds) Nordic Perspectives on Process-Based Regional Development Policy, Nordregio report 2002:3, Stockholm.

BRUUN, H., HÖYSSÄ, M. and HUKKINEN, J. (2001) The Making of Biocity, A Study of the Birth a Biotechnology Centre in Turku, Finland, Manuscript.

CHATTERTON, P. and GODDARD, J. (2000) The Response of Higher Education Institutions to Regional Needs. European Journal of Education, vol. 35, no. 4, pp. 475-96.

COHEN, W., NELSON, R. and WALSH, J. (2002) Links and Impacts: The Influence of Public Research on Industrial R\&D, Management Science, Vol. 48, No. 1, pp. 1-23

COOKE, P. (2002) Towards Regional Science Policy? The Rationale from Biosciences, Prepared for Conference on 'Rethinking Science Policy: Analytical Frameworks for Evidence-Based Policy', SPRU, University of Sussex, March 21-23, 2002.

COOKE, P., HEIDERICH, M. and BRACZYK H-J. (Eds.) 2004. Regional Innovation Systems. The role of governance in the globalised world. 2nd Edition. London; New York 2004, Routledge. CURZIO, A. and FORTIS, M. (Eds) (2002) Complexity and Industrial Clusters: Dynamics and Models in Theory and Practice. Physica-Verlag.

DASGUPTA, P. and DAVID, P (1994) Towards a New Economics of Science, Research Policy $23(5), 487-521$

DELANTY, G. (2001) Challenging Knowledge, Open University Press, Buckingham.

EISENBERG, R. S. and NELSON, R.R. (2002) Public vs. Proprietary Science: A Fruitful Tension? Daedalus, Journal of the American Academy of Arts and Sciences, Spring, Volume 131, no.2. ESPING-ANDERSEN, G (1999) Social Foundations of Postrindustrial Economies, Oxford, UK and New York, USA, Oxford University Press. 


\section{ETZKOWITZ, H. and LEYDESDORFF (2000) The Dynamics of Innovation: From National} Systems and 'Mode 2' to a Triple Helix of University-industry-government Relations, Research Policy, no. 29, pp. 109-123.

FELLER, I. (2004) Virtuous and Vicious Cycles in the Contributions of Public Research Universities to State Economic Development Objectives, Economic Development Quarterly, Thousand Oaks, May 2004, Vol. 18, Iss. 2, p. 138-150

GIBBONS, M., LIMOGES, C., NOWOTONY, H., SCHWARTZMAN, S., SCOTT, P. and TROW, M. (1994) The new production of knowledge, Sage, London.

Goddard, J.B. (1999) Universities and regional development: an overview, in GRAY, G. (Ed) Universities and the Creation of Wealth, Milton Keynes, Open University Press.

GODDARD, J., TEICHLER, U., VIRTANEN, I. and WEST, P. (2000) External Engagement and Institutional Adjustment: An Evaluation of the University of Turku. Publications of the Finnish Higher Education Evaluation Council 3:2000, Edita, Helsinki.

GODDARD, J., ASHEIM, B. T., CRONBERG, T. and VIRTANEN, I., (2003a) Learning Regional Engagement. A Re-evaluation of the Third Role of Eastern Finland Universities. Publications of the Finnish Higher Education Evaluation Council 11:2003, Edita, Helsinki.

GODDARD J., TEICHLER U., VIRTANEN I., WEST P., and PUUKKA, J. (2003b) Progressing external engagement. A re-evaluation of the third role of the University of Turku. Publications of the Finnish Higher Education Evaluation Council 16:2003, Edita, Helsinki.

GULBRANDSEN, J. and SMEBY, J-C. (2002) The external orientation of university researchers: implications for academic performance and management, Paper for the 4th Triple Helix Conference, Copenhagen, November 2002

HARLOE M. and PERRY B. (2004) Universities, Localities And Regional Development: The Emergence Of The 'Mode 2' university? International Journal Of Urban And Regional Research, 28 (1): 212-+ March. 
HERMANS, R. and TAHVANAINEN, A-J. (2002) Ownership and Financial Structure of Biotechnology SMEs: Evidence from Finland, ETLA publication no 835, 2002.

HERMANS, R. and KULVIK, M. (Eds) (2006) Sustainable Biotechnology Development - New Insights into Finland. ETLA B 217.

HODGSON, G. (1988) Economics and Institutions, A Manifesto for a Modern Institutional Economics, Polity Press and Blackwell Publishers, UK.

HODGSON, G. (2006) What are Institutions?, Journal of Economic Issues, 40 (1), March, 1-25.

HODGSON, G. (2003) The Hidden Persuaders: Institutions and Individuals in Economic Theory, Cambridge Journal of Economics 27, No. 2, March, 159-175.

HOLLAND, B.A. (2001) Toward a definition and charcterization of the engaged university. Metropolitan Universities, 2(3), 20-29.

HÖYSSÄ, M., BRUUN, H. and HUKKINEN, J. (2003) The Co-Evolution of Social and Physical Infrastructure for Biotechnology Innovation in Turku, Finland. Research Policy, Volume 33, Issue 5, July 2004, Pages 769-785

ISPE (2003) A look at the Pharmaceutical Industry in the Nordics, Pharmaceutical engineering May/June 2003 Volume 23, Number 3.

JASANOFF, S. (2003) Technologies of Humanity: Citizen Participation in Governing Science, Minerva 41, 223-244.

JOLKKONEN, A. (1985) Korkeakoululaitoksen muotoutuminen ja uudet tehtävät. (The formation and new functions of the university), Faculty of Education, University of Joensuu.

KANKAALA, K., KAUKONEN, E., KUTINLAHTI, P., LEMOLA, T., NIEMINEN, M. and VÄLIMAA, J. (Eds.) (2004) Yliopistojen kolmas tehtävä? ('The Third Role of the Universities?”) Finnish national Fund for Research and Development SITRA. SITRA Publications 264. Edita, Helsinki. 
KOSONEN, P. (1987) Hyvinvointivaltion haasteet ja pohjoismaiset mallit. (Challenges and Nordic models of welfare state), Mänttä, Vastapaino.

LAWTON SMITH, H. (2003) Knowledge Organizations and Local Economic Development: The Cases of Oxford and Grenoble, Regional Studies, Vol.37, No.9 pp.899-909.

LUNDVALL, B- Å. (1988) Innovation as an interactive process: From user-producer interaction to the national system of innovation, in DOSI, G., FREEMAN, C., NELSON, R., SILVERBERG, G. and SOETE, L. (Eds.) Technical Change and Economic Theory, London, Pinter, 349-369.

LUNDVALL, B-Å. (1992) User-Producer Relationships, National Systems of Innovation and Internationalization, in LUNDVALL, B- $\mathrm{A}$ (Ed) National System of innovation and interactive learning, New York, Pinter.

MALERBA, F. (2002) Sectoral systems of innovation and production, Research Policy, Vol. 31, pp. $247-264$

MARTIN, B.R. and ETZKOWITZ, H. (2000) The Origin and Evolution of the University Species, Vest 13 (3-4), 9-34.

MIETTINEN, R., TUUNAINEN, J., KNUUTTILA, T. and MATTILA, E. (2006) Tieteestä tuotteeksi, Yliopistotutkimus muutosten ristipaineessa, Helsinki University Press.

MINISTRY OF EDUCATION (2001) Korkeakoulujen alueellisen kehittämisen työryhmän muistio [Memo by the working group for regional development of higher education institutions]. Opetusministeriön työryhmien muistioita 28:2001, Ministry of Education, Helsinki. MOWERY, D. and SAMPAT, B. (2004) Universities in National Innovation Systems, in FAGERBERG, J., MOWERY ,D. and NELSON, R. (Eds) The Oxford Handbook of Innovation, Oxford University Press.

NELSON, R.R. (Ed) (1993) National Systems of Innovation: A Comparative Study, Oxford, Oxford University Press. 
NIEMINEN, M. and KAUKONEN, E. (2001) Universities and R\&D networking in a knowledgebased economy: A glance at Finnish developments, Sitra, Sitra Report Series 11, Helsinki.

NIEMINEN, M. and KAUKONEN, E. (2004) Universities and science-industry relationships: Making a virtue out of necessity?, in SCHIENSTOCK, G. (Ed) Embracing the Knowledge Economy. The Dynamic Transformation of the Finnish Innovation System, Cheltenham and Northampton: Edward Elgar

NORTH, D. (1990) Institutions, Institutional Change, and Economic Performance, Cambridge University Press, New York.

NOWOTNY, H., SCOTT, P. and GIBBONS, M. (2001) Rethinking Science. Knowledgeand the Public in an Age of Uncertainty, Cambridge, Polity

OECD (1999) The Response of Higher Education Institutions to Regional Needs, Centre for Educational Research and Innovation (CERI/IMHE/DG(96)10/REVI), OECD, Paris.

ORAVA, M., BRÄNNBACK, M., RENKO, M., SUONIEMI, S., SÖDERLUND, S. and WIKLUND, P. (2001) Turun Bioalan Riskianalyysi (Risk analysis of bio-sector in Turku), Innomarket, Turku School of Economics and Business Administration.

POLT, W., RAMMER, C., SCHARTINGER, D., GASSLER, H. and SCHIBANY, A. (2001) Benchmarking Industry-Science Relations in Europe - the Role of Framework Conditions, Project commissioned by the European Commission, DG-Enterprise and the Austrian Federal Ministry for Economic Affairs and Labour (BMWA), Brussels, European Commission.

ROSENBERG, N. and NELSON, R. (1994) American universities and technical advance in industry, Research Policy 23, 323-348

RUTHERFORD, M. (1994) Institutions in Economics, The Old and New Institutionalism, Historical Perspectives on Modern Economics, Cambridge University Press, Cambridge, UK. SÁBATO, J. and MACKENZI, M. (1982) La producción de Technología. Autónoma o Transnacional. Nueva Imagen, Mexico. 
SANTOS, F. (2003) The coevolution of firms and their knowledge environment: Insights from the pharmaceutical industry, Technological Forecasting \& Social Change 70(2003) 687 - 715.

SCHIENSTOCK, G. and HÄMÄLÄINEN, T. (2001) Transformation of the Finnish innovation system: A network approach, Sitra, Sitra Report series 7, Helsinki.

SCHIENSTOCK, G. and TULKKI, P. (2001) The Fourth Pillar? An assessment of the situation of the Finnish biotechnology, Small Business Economics, An International Journal, Vol. 14. Issue 4. Kluwer Academic Publishers.

SCIENCE and TECHNOLOGY POLICY COUNCIL OF FINLAND (2000) Katsaus 2000: Tiedon ja osaamisen haasteet (Review 2000: The challenges of knowledge and know-how), Helsinki, Science and Technology Policy Council of Finland.

\section{SCIENCE AND TECHNOLOGY POLICY COUNCIL OF FINLAND (2003) Osaaminen} innovaatiot ja kansainvälistyminen (Knowledge, innovation and internationalization), Helsinki, Science and Technology Policy Council of Finland.

SCOTT, R.W. (2001) Institutions and Organisations, $2^{\text {nd }}$ Ed., Sage Publications, London.

SLAUGHTER, S. and LESLIE, L. (1997) Academic Capitalism, The Johns Hopkins University Press, Baltimore/London.

SOTARAUTA, M and SRINIVAS, S. (2006) Co-evolutionary Policy Processes: Understanding Innovative Economies and Future Resilience. Futures, 38 (3), April.

SRINIVAS, S., VILJAMAA, K. (2003) BioTurku: “Newly” innovative? The rise of biopharmaceuticals and the biotech concentration in southwest Finland, MIT IPC Local Innovation Systems Working Paper 03-001, Industrial Performance Centre, Massachusetts Institute of Technology, Cambridge, MA.

SRINIVAS, S., KOSONEN, K-J, NUMMI, J., VILJAMAA, K. (2005) How public is publiclyfunded knowledge? The Dynamics of R\&D Projects, MIT IPC Local Innovation Systems 
working paper, Industrial Performance Centre, Massachusetts Institute of Technology, Cambridge, MA.

STOKES, D. E. (1997) Pasteur's Quadrant: Basic Science and Technological Innovation, Washington D.C., Brookings Institution Press.

TOMLIN, R. (1999) University of Turku-External Impact of Research, Technology Transfer and Regional Liaison Activities, University of Newcastle upon Tyne, Centre for Higher Education Research.

Turku Biotechnology Strategy (2004), Bio Turku, Unpublished.

VIRTANEN, I. (2002) Yliopistojen kolmas tehtävä [The Third Role of Univeristies], Polemia- sarja no 44, Kunnallisalan kehittämissäätiö, Vammala, Finland.

YLIJOKI, O-H. (2003) Entangled in academic capitalism? A Case-Study on changing ideals and practices of university research, Higher education, 45, 307-335.

ZIMAN, J. (1996) "Post-academic science": Constructing knowledge with networks and norms, Science Studies 9(1), 67-80. 
1889-1925 Start of Finnish pharma industry, Generics manufacturing, mass production 1940s 1925-1980s 1970s

Late 1980s

1989-1994

$1994-2002$

$2002-$

Farmos and Leiras start bases in Turku

Companies mostly acquiring foreign licenses to sell domestically.

Move to greater trade. More $R \& D$ investments but greater generics sales to USSR

Product patents adopted in many other countries. Anticipation of EU membership

Recession, loss of USSR generics markets, M\&A in pharma in global pharmaceutical industry, joining EU, shift to EU product patent regime, Turku starts BioCity

EU entry, further focus on R\&D, consolidation of drug development R\&D projects in Turku firms, layoffs, biotech start-ups and spin-offs arise, Turku pushes to develop a nationally recognises biotech base.

Financial pressures and mergers in smaller companies, institutionalisation of Bio Turku

Table 1. Turning points for the Turku pharmaceutical industry (Source: SRINIVAS and VILJAMAA, 


\begin{tabular}{lcccc}
\hline & Academy of Finland & $\%$ & TEKES & $\%$ \\
\hline Turku & 7804 & 20,1 & 9626 & 42,6 \\
-BioCity Turku & 5879 & 15,1 & 5188 & 22,9 \\
-University of Turku & 1176 & 3,0 & 4094 & 18,1 \\
-Åbo Akademi & 749 & 1,9 & 344 & 1,5 \\
Helsinki & 19642 & 50,6 & 8133 & 36,0 \\
Other regions & 11368 & 29,3 & 4852 & 21,5 \\
\hline Total (Universities and Biocentres) & 38814 & 100,0 & 22611 & 100,0 \\
\hline
\end{tabular}

Table 2. Academy of Finland and TEKES financing to biotechnology 2001 (Source: Biotechnology in Finland, 2002) 